\title{
ARISTOTELIAN CORPORATE GOVERNANCE
}

\author{
Alejo José G. Sison
}

University of Navarre

I. Introduction

II. What kind of community is the firm?

1. The firm as an artificial and imperfect society, the firm as an intermediate body

2. The economic end of the firm

III. The common good of the firm

1. The political common good and the corporate common good

a. Aristotle and the common good of the polis

b. Aquinas on God as the common good

2. The structure of the corporate common good and subsidiarity

IV. Conclusion: corporate governance as praxis and the common good

\section{Introduction}

Elsewhere (Fontrodona and Sison 2006, Sison 2007, Sison 2008), I had laid out and argued against the different theories that configure today's dominant conception of the firm, its assumptions regarding human beings and their behavior, and the corporate governance model it proposed. According to the neoclassical paradigm (Roberts 2004), further enriched with contributions from transaction cost economics (Coase 1937), shareholder theory (Friedman 1970) and agency theory (Jensen and Meckling 1976), the firm is fundamentally a nexus of contractual relationships between shareholderprincipals and manager-agents for the purpose of maximizing the value of the shareholder-principals’ investments.

These doctrines imply that human beings are, before anything else, economic agents, fully constituted as individuals, that is, independently of all social bonds. They manifest rationality precisely by choosing, among available options, that which promises the highest returns in terms of utility. Although in the end, utility - money or power - requires transformation into pleasure or psychological satisfaction in order to actually benefit human beings, it is nevertheless posited as the supreme good or object of desire. Human actions are to be evaluated solely on the basis of consequences, in 
particular, their usefulness in bringing about states of satisfaction. Just like any other organization, the business firm functions as the result of more or less coordinated individual actions. The key to corporate governance, therefore, lies in subverting through contracts the utility of other agents (mainly managers) so much so that it becomes aligned with the interests of shareholders.

Very little of the different premises that served to support the neoclassical theory of the firm would be of use in articulating an Aristotelian version of the corporate common good and corporate governance. The main reason is that the kind of activity they describe does not qualify, strictly speaking, as human action (praxis). At most, it belongs to the category of artisinal production (poiesis, techne) in Aristotle's own classification or theory of action. It refers to activities befitting slaves or guest foreign workers - no matter how knowledgeable or expert they may be — but not free men or citizens, in accordance with the characteristics of the social classes in Aristotelian politics. These activities are carried out primarily for the production of an external good, a material object or service (extended to mean utility, profit or shareholder value) and not for the agent himself, his technical, intellectual, cultural or moral growth and improvement (in a word, virtues).

Much has already been said, by way of criticism, of the individualism, utilitarianism and consequentialist reasoning deeply embedded in the neoclassical economic conception of the firm. Similarly, much has been written with regard to the corollary theories of why production should be carried out in the firm instead of the market, how the relationship between capital providers and manager-employees should be framed, and what the firm's overarching purpose ought to be. Certainly, transaction cost economics could explain the existence of the firm vis-à-vis the market because of greater efficiency, and agency theory could provide an economic and legal template for the contract between workers and capitalists. But in themselves they do not give reasons why efficiency should be measured in terms of shareholder value maximization, nor for the underlying social web that makes contractual agreements possible. Although in the past, I myself have offered my own reading of these issues, this time, I would like to take a different focus. This paper intends to have a more constructive outlook and explain how Aristotelian corporate governance founded on the corporate common good might be conceived, taught and practiced. 
In light of the foregoing, Aristotelian corporate governance requires a radical change of tack from conventional theories. I shall attempt to develop this broad theme in three major stages. First, I will render something that could pass for an Aristotelian theory of the firm, fully aware that Aristotle himself did not deal with such an institution in his writings. I will have to provide an account of the proper locus and purpose of the firm within the overall context of society. Secondly, I will offer, through an analogy with the common good of the polis or the state, an account of the common good of the firm. I should also propose ways in which the particular common good of the firm could be integrated or subordinated to the wider common good of the political community. Lastly, I will try to explain the theory and practice behind what could stand as Aristotelian corporate governance, one that seeks to achieve the corporate common good.

II. What kind of community is the firm?

1.The firm as an artificial and imperfect society, the firm as an intermediate body

On account of their end or purpose, states are considered by Aristotle in the Politics to be "natural" and "perfect" societies. By contrast, therefore, modern day corporations could be characterized as examples of "artificial" and "imperfect" associations.

The state, like the family and the village, is a "natural" society, because it stems from an innate tendency in human beings (Politics, henceforth Pltcs 1252b). The family, which issues from the union of man and woman as husband and wife, is "natural" because it arises in response to a deeply felt need in human beings to leave behind living images of themselves in and through their children. The village, too, is "natural" because the human instinct for self-preservation requires that one look beyond the daily needs satisfied within the household to the requirements of a longer term of existence. The village — which includes children, grandchildren and other relatives by blood or marriage - is, in this sense, like a prolongation or extension of one's original family. Next down this line of "natural” institutions comes the state, which results from several villages being united in a single, complete community. 
From among these three "natural" institutions, however, only the state is "perfect" because it alone is "self-sufficing” for the good life. Not only day to day needs, but also those of a life whole and entire can be expected to be met within the bounds of the state. Only in the state can human beings truly aspire to live a completely good life. The state thus represents the "end" or "final cause", the fully developed stage of human existence (Pltcs 1252b). For this reason, although the state may be considered chronologically posterior to both the family and the village, it is in reality prior to them: "The proof that the state is a creation of nature and prior to the individual is that the individual, when isolated, is not self-sufficing; and therefore he is like a part in relation to the whole" (Pltcs 1253a). Individuals, then, just like the families and the villages they form, are like parts with respect to the whole represented by the state. Moreover, although nature has implanted in all human beings a social instinct, only in the state can this innate tendency be fully developed and perfected through the institutions of law and justice. Otherwise, outside of the state, human beings become the most savage and worst of animals (Pltcs 1253a).

Within the context of Aristotle's political architecture, just how does the firm fit? First of all, although Aristotle does not mention business firms and corporations in the Politics, we could find allusions to them in the "family connections, brotherhoods, common sacrifices and amusements” (Pltcs 1280b) that draw human beings together. In contrast with the family and the village, and most importantly, with the state, the firm may be considered an "artificial" society because it arises neither directly nor organically from human nature. Rather, the firm is based on voluntary bonds of "friendship" — a foreshadowing of contracts — primarily among citizens of the same state. It is also called an "imperfect" society because it is not self-sufficing for the good life. A business corporation is an example of an "intermediate body or association" situated between individuals and their families, on the one hand, and the state, on the other. As such, it is not meant to substitute the family in the provision of the daily needs for survival, nor the state as the proper locus of a full and flourishing human life. Rather, like all other intermediate bodies, its purpose is to supply some of the necessary means — in this particular case, goods and services — for the good life in the state (Pltcs 1280b). 
2.The economic end of the firm

In the welter of intermediate bodies normally found in a healthy state, a special place is reserved for those that broadly seek economic ends, and it is among these that we include firms and business corporations. A primarily economic focus distinguishes businesses from other possible intermediate groups such as churches, professional colleges, sports associations, neighborhood councils, cultural clubs and the like. It's not that these other intermediate bodies lack any economic dimension or significance; it's just that such an economic dimension or significance is not their main concern, unlike firms and business corporations.

Business firms and corporations, then, are intermediate bodies that pursue economic goals. But what exactly are these goals?

Returning once more to Aristotle's Politics, we are told that the economy was born within the family, as "household management" (Pltcs 1253b). His treatment of the economy in its original, etymological meaning of "household management" begins with a survey of the different parts necessary for a complete household and the relationships among them: "the first and fewest possible parts of a family are master and slave, husband and wife, father and children. We have therefore to consider what each of these three relations is and ought to be: - I mean the relation of master and servant, the marriage relation (the conjunction of man and wife has no name of its own), and thirdly, the paternal relation (this also has no proper name)” (Pltcs 1253b).

Early in his discussion of the economy as household management, Aristotle distinguishes between the art of household management in itself and the art of getting wealth or chrematistics (Pltcs 1253b). In both arts, however, Aristotle acknowledges the difference between a natural and a non-natural form.

Natural chrematistics pertains to the provision of "such things necessary to life, and useful for the community of the family or state, as can be stored” (Pltcs 1256b), whereas non-natural chrematistics, of "riches and property [which] have no limit" (Pltcs 1267a). Natural wealth-getting is based on the premise that true riches, the kind and amount of property needed for a good life is not without limit. There is a level beyond 
which the mere accumulation of material things becomes more of a nuisance or a liability to human flourishing than an advantage or help. Nowadays, one could think of having more cars than could fit in the garage, or more foodstuffs than the refrigerator could store, for example.

Non-natural wealth-getting, on the other hand, believes that "more is always better" and that for the good of the economy there should be no stop in piling up possessions. Although the example may be a bit dated, by non-natural wealth-getting Aristotle referred primarily to retail trade and exchange, which allowed one to accumulate riches in the form of money or coin, practically without limit. But "coined money is a mere sham, a thing not natural, but conventional only, because, if users substitute another commodity for it, it is worthless, and because it is not useful as a means to any of the necessities of life, and, indeed, he who is rich in coin may often be in want of necessary food. But how can that be wealth of which a man may have great abundance and yet perish with hunger...?” (Pltcs 1257b). Somehow we can still relate to the situation Aristotle describes if we imagine ourselves in a foreign country without the proper currency or where our credit cards are not honored. Whatever wealth or money we think we have is rendered useless, unable to pay even for a piece of bread.

However, the art of household management or economy properly speaking seems to refer more to the use of property rather than to its acquisition, Aristotle implies. Once again, in the use of property or its corresponding art we ought to differentiate between the natural or proper and the non-natural or improper. Take the case of a shoe: if it is used for wear, one makes a proper use, while if it is used for exchange, one makes an improper use, "for a shoe is not made to be an object of barter" (Pltcs 1257a). The proper use of any material possession acknowledges a limit or a further end that makes the activity honorable, whereas its improper use is void of limit and thus becomes censurable. To illustrate this unnatural and inappropriate use of wealth - once more, within the context of a primitive economy- Aristotle points out to "usury, which makes a gain out of money itself [...] For money was intended to be used in exchange, but not to increase at interest” (Pltcs 1258b).

It is important to realize that, both in the acquisition and the use of wealth, the difference between the natural and the non-natural depends more on the dispositions of 
human beings than on the material things themselves (Pltcs 1257b-1258a). Unbridled desires, the want of wealth and pleasure or enjoyment untutored by virtue, lead human beings to non-natural forms of getting and using material possessions. This way, unbeknownst to them, their search for happiness or flourishing becomes self-defeating. Failure then won't be the fault of the material things but of their own vices.

Speaking about the non-natural art of chrematistics or wealth-getting in which business firms and corporations ultimately engage, Aristotle states that "in the first community, indeed, which is the family, this art is obviously of no use, but it begins to be useful when the society increases. For the members of the family originally had all things in common” (Pltcs 1257b). The next stage, characterized by a still natural form of chrematistics, begins when the family grows and becomes big enough to be "divided into parts, the parts shared in many things, and different parts in different things, which they had to give in exchange for what they wanted, a kind of barter [...]; giving and receiving wine, for example, in exchange for corn, and the like” (Pltcs 1257a). Finally, non-natural chrematistics inevitably takes place when a society's needs becomes more complex. Together with it comes the widespread use of money and the establishment of the first businesses or firms. As Aristotle relates, "when the inhabitants of one country became more dependent on those of another, and they imported what they needed, and exported what they had too much of, money necessarily came into use” (Pltcs 1257a). These new functions resulting from the development of the economy and society can only be carried out effectively by larger organizations such as corporations or firms, understood as extensions of the family or "economic friendships” (Pltcs 1280b).

Insofar as business firms and corporations play a role in the production of goods and services, they operate within the realm of wealth-getting or chrematistics. And inasmuch as business firms and corporations are artificial societies, they are meant as a help or complement to the material resources that nature, in principle, ought to provide. In other words, the activity of business firms and corporations forms part of the socalled non-natural chrematistics. What is clear by Aristotle's reckoning is that business firms and corporations only fulfil a subordinate or secondary function in the economy, which "attends more to men than to the acquisition of inanimate things, and to human excellence more than to the excellence of property which we call wealth, and to the excellence of freemen more than to the excellence of slaves” (Pltcs 1259b). That is to 
say, the main purpose of the economy is to facilitate the development of human excellence or virtue by guaranteeing — to the extent possible — the material conditions for its practice. And virtue, in turn, is sought primarily because it affords us happiness, a good, flourishing life.

Getting back to our initial query of how business firms and corporations fit in the state, we can now say, in accordance with Aristotle's teachings, the following. As a class of artificial intermediate bodies, business firms and corporations belong to the realm of the economy. In particular, their purpose is the non-natural acquisition or provision of material goods beyond the capabilities of the family. Resulting from a variant of the art of wealth-getting or chrematistics, business firms and corporations should be subject to the superior art of the economy itself, which consists in the administration and use of material goods. All economic activity in turn - and the institutions it gives rise to, such as business firms or corporations and the marketshould function under the guidance of ethics, which is the "practical science" or art of virtue. The economy has as its mission to facilitate the practice of virtue by establishing favorable material conditions among the citizens of a state. And virtues, in the final analysis, are sought insofar as they help us attain happiness or a flourishing life in the state, under the tutelage of politics.

Only within this hierarchy of disciplines and institutions, each one with its own proper object, can the true role of business firms and corporations within society be ascertained. Because "the end of the state is the good life, and these [i.e., family connections, brotherhoods, common sacrifices and amusements, and by extension, firms] are the means towards it” (Pltcs 1280b). The economic ends that corporations seek are simply means to the political end that city-states for their part propose. The production of goods and services which is the purpose of business corporations and firms is not at all self-justifying. It is desirable and acquires meaning only insofar as it contributes to a flourishing life in the state. Later on we shall have the occasion to draw from here implications for the proper governance of business corporations and firms.

III. The common good of the firm

1. The political common good and the corporate common good 
The notion of the common good was initially formulated by Aristotle with reference to the polis. It is none other than eudaimonia or the full flourishing of human beings as citizens of the well-ordered polis. To the extent that he was Aristotle's follower and commentator, Thomas Aquinas was met with the challenge of making room for the Judeo-Christian God within the general notion of the common good, while keeping intact the aspect of human flourishing. Largely through the use of analogy, he was able to make the connection between God and human fulfilment, conveniently recast as beatitudo or blessedness. As heir to Aristotelian and Thomistic teachings on the common good, Church Social Doctrine develops the concept further by highlighting its historical conditioning or determination. Modern scholars have likewise proposed a hierarchical structure or guide through which the political common good could be attained, under varying socioeconomic and cultural circumstances.

However, the crucial link that renders possible the inception of a common good proper to the firm as an intermediate body and the political common good is the Church Teaching on work. Despite using Aristotelian and Thomistic terminology, the content is radically new yet potent enough to meet all the requirements that have so far been established. This will be the ground of what I hope to explain as an Aristotelian-inspired theory of the firm, and consequently, an Aristotelian-inspired theory of corporate governance as well.

a. Aristotle and the common good of the polis

What is the "good"? In the opening lines of the Nicomachean Ethics, Aristotle defines the good as "that at which everything aims" (Nicomachean Ethics, henceforth NE 1094a), the end of a given appetite, desire, inclination or tendency. Basing himself on Aristotle, Aquinas explains that the good perfects being not only by way of knowledge, as with the truth, but also in reality, as the best state of being in itself ( $D e$ Veritate q. 21, a. 1, c). Elsewhere he teaches that the good is an aspect of all being, insofar as it is an object of desire, is perfect and in act (ST I, q. 5, a. 1, c). We call something "good", therefore, inasmuch as it is or exists and in the measure that it has reached its end or perfection, being able to transmit this perfection to others. 
And what about the "common good"? For Aristotle, the common good has to do with the polis: "the good of the polis is apparently greater and more complete good to acquire and preserve. For while it is satisfactory to acquire and preserve the good even for an individual, it is finer and more divine to preserve it for a people and for poleis [the plural form of polis]” (NE 1094b). The common good, the good of the polis, is thus explained in contrast to the exclusive good of the individual, which is inferior. Aquinas is even more explicit in his commentary: the common good as a cause is "more divine because it shows greater likeness to God, who is the ultimate cause of all good" (Comm. NE I, 2, 30).

Apart from the common good and the good exclusive to an individual, we find in the Nicomachean Ethics yet another classification of goods: those pursued in themselves and those pursued because of another. Aristotle indicates that a good pursued in itself is always better because it is complete (NE 1097a). Among the different possible goods pursued in themselves, eudaimonia or "happiness", a flourishing human life, stands out as most choiceworthy, complete and self-sufficient (NE 1097b). This self-sufficiency, however, needs clarification: "not what suffices for a solitary person by himself, living an isolated life, but what suffices also for parents, children, wife and in general for friends and fellow-citizens, since a human being is a naturally political [animal]” (NE 1097b). Thus, eudaimonia consists in a good life in common, shared with one's family, friends and fellow-citizens in the polis. Not only is this the supreme human good but it is also the common good.

By and large, Aristotle's Politics is nothing else but a treatise on how full human flourishing can be achieved within the polis (Pltcs 1252a). This depends on the manner in which the polis is governed. The plurality of political regimes is a function of the number of people who govern and, more importantly, for whose good, advantage or interest they govern. In this respect, "governments which have a regard to the common interest [sumpheron koinon] are constituted in accordance with strict principles of justice, and are therefore true forms; but those which regard only the interest of the rulers are all defective and perverted forms, for they are despotic, whereas a polis is a community of freemen” (Pltcs 1279a). Further specifications are made, such that true forms of government are divided into “monarchies”, “aristocracies” and “constitutional rules”, when only one, a few and many rule, respectively (Pltcs 1279a-b). In a similar 
way, with the defective forms of government, one can distinguish among "tyrannies", “oligarchies” and “democracies", depending on the number of rulers: "For tyranny is a kind of monarchy which has in view the interest of the monarch only; oligarchy has in view the interest of the wealthy; and democracy, of the needy: none of them the common good [agathon koinon] of all” (Pltcs 1279b). The regard for the common good, therefore, serves as criterion for determining whether a polis is properly governed and achieves its goal of eudaimonia.

A few explanations are in order concerning the expression sumpheron koinon, “common interest or advantage”, which Aristotle prefers, and agathon koinon, “common good”, which he uses rather sparingly. (Aquinas, for his part, also speaks of utilitas communis, “common utility”, and bonum commune, “common good”, quite indistinctly.) Unlike their translations into modern English and most other European languages contaminated by utilitarian thinking, nothing in the original texts deters us from understanding both terms as synonymous. Michael A. Smith, in an excellent monograph, suggests that Aristotle employed sumpheron koinon, "common interest or advantage”, to distance himself from the Platonic Idea of the Good: "the good, for Aristotle, is the good of someone or something. The common good is the good of all members of a political community once these members have actualized their disposition to live in common. They organize themselves in view of the good which political life can provide them, they enjoy the advantages of life in common. And these advantages can vary from one period of time to another, and also from one place to another" (Smith 1995: 63).

The common good which Aristotle proposes is concrete, contingent in time and place, and specific to a polis. That's why he declares, in allusion to Platonic doctrine, that "even if the good predicated in common is some single thing, or something separated, itself in itself, clearly it is not the sort of good a human being can pursue in action or possess" (NE 1096b). Knowing fully well that such notion of the good would have been unconscionable for Plato, nonetheless Aristotle as a philosopher insists that "it presumably seems better, indeed only right, to destroy even what is close to us if that is the way to preserve the truth" (NE 1096a). 
How do individuals in the polis relate to the common good? They share or take part in the common good through citizenship. In the Politics, Aristotle introduces the institution of citizenship upon observing that the "polis is composite, [and] like any other whole [is] made up of many parts — these are the citizens, who compose it” (Pltcs 1274b).

According to Aristotle, "a citizen in the strictest sense" is he who "shares in the administration of justice, and in offices" (Pltcs 1275a). The essential task of the citizen is to participate in deciding what is good and just in the polis and in putting this into effect. A citizen is a "juryman and member of the assembly", to whom "is reserved the right of deliberating or judging about some things or about all things” (Pltcs 1275b). Although many people in a polis may actually participate in the process of deliberating and deciding on the common good, only citizens do so by right. What characterizes a citizen, therefore, is "the power to take part in the deliberative or judicial administration of any polis" (Pltcs 1275b). This does not mean, however, that a citizen always has to hold public office. It suffices that he at least have the power to occupy such a post, for citizenship requires "sharing in governing and being governed" (Pltcs 1283b). The common good is the product of the joint deliberation, decision and action of the citizens of a polis.

To the extent that citizens are involved in deciding the common good and in dispensing justice, they are like the soul, the most important element in the polis. Aristotle states that "as the soul may be said to be more truly part of an animal than the body, so the higher parts of the polis, that is to say, the warrior class, the class engaged in the administration of justice, and that engaged in deliberation, which is the special business of political understanding - these are more essential to the polis than the parts which minister to the necessaries of life” (Pltcs 1291a). Certainly, citizenship affords one the possibility to participate in the common good, preeminently, in government, by deliberating and administering justice; although it does not in fact guarantee an equal share for all.

In summary, for Aristotle, the common good is the good of the polis and of each and every citizen. Another name for it is eudaimonia, which is also man's highest good because of his social nature. In the study of politics, the common good of the polis is the 
criterion for distinguishing true, just or constitutional regimes from false, perverse or despotic rules. By virtue of their citizenship, human beings are able to participate in the common good, primarily — though not exclusively - by sharing in government or the administration of justice.

b. Aquinas on God as the common good

What modifications does Aquinas introduce to the Aristotelian understanding of the common good? Being a Christian philosopher, Aquinas could no longer accept the earthly polis as the highest community to which human beings belong and in which they achieve their ultimate perfection. Because of this, he was somewhat forced to elaborate a richer conception of the common good that could, above all, accommodate God and communion with Him. He was able to do this through the use of analogy, although he himself did not elaborate an analogy of the common good, properly speaking. However, in every one of the terms to which he applies the "common good", its fundamental nature as the good of the whole and of each of its parts remains unchanged (Froelich 1989: 42).

In a short theological treatise describing the perfection of the spiritual life, Aquinas writes: "in this community by which all people agree on happiness as an end, each and every man is considered as a certain part: but the common good of the whole is God himself, in whom consists the happiness of all” (De perfectione vitae spiritualis, c. 13, n. 634). For Aquinas, God is not only the common end or perfection of every human being and of the whole human species, but He is also the ultimate cause of all good. Such an affirmation, of course, concurs with Aquinas' idea of God as the supreme being.

What's the relation between God and other common goods, such as eudaimonia in the earthly polis? Among the different terms to which the expression "common good" applies in Aquinas, one could establish an analogy of proportionality (Smith 1995: 7274). “Common good” refers more properly to a final cause than to a mere logical predicate. There are at least two ways in which the "common good" acts as a final cause or common end of the whole human species and of every human being: first, in the case of God, as an extrinsic, ontological and speculative common good, and second, in the 
case of eudaimonia in the earthly polis, as an intrinsic, social and practical common good. The first fulfills the nature of the common good better and on it depends the second, as we shall later on see. To the second, eudaimonia as the political common good, are subordinated the bona communia (Comm. NE I, 7, 95), the means or instruments for its preservation.

The bona communia constitute an "integral whole" which, in turn, could be divided into formal or material parts, and subsequently, into act or potency. For example, water in a public reservoir is an "integral whole" divisible into material parts as a common good in potency. It never really is a good unless it has already been divided and distributed among the many different persons who use it for drinking or washing. Insofar as the quantity of water diminishes as it is divided and distributed, this "integral whole" is composed of material parts. And in the measure that the water one uses for drinking or washing cannot be used by another, this "integral whole" cannot be a common good in act, but only in potency. In this sense, water is one of the bona communia, the material and potential common goods that are to be distributed as means or instruments in accordance with distributive justice among the members of the polis.

A different "integral whole" is that instantiated by a well-functioning polis, characterized by the rule of justice and law, where each citizen is a formal-rational part that cannot be replaced by another (unlike material parts). Inasmuch as each human being already is a substantial unity, together they could only form unities of order as the family or the polis. And to the extent that a flourishing life in common or eudaimonia is the good sought in the polis, it never is simply a potential common good, but always an actual one. Furthermore, due to the uniqueness of every human being, no one could be substituted by another, strictly speaking, in the family, polis or any other group.

Notice that eudaimonia does not diminish as the number of citizens who participate in it increases; on the contrary, it becomes even greater. In this regard, eudaimonia is similar to what has come to be known in modern economic theory as a "public good" or a "collective consumption good", characterized by nonrivalrous and nonexcludable consumption (Samuelson 1954). Unfortunately, precisely because of these traits, these goods encourage free-riding and chronic underinvestment. 
Since all intrinsic orders — such as the family, the polis or the whole universe, for that matter - necessitate an extrinsic cause, they cannot but point to a separate being as their final cause and ultimate end. This separate being which, in a sense, is its own cause and explains and causes all other intrinsic orders in the universe is God himself; He is their common good, end and perfection. From the viewpoint of human beings as rational creatures, God alone is the extrinsic, ontological and speculative common good: "extrinsic" because he is separate from the whole universe as its primary cause, “ontological” because he is a being unto himself rather than a mere unity of order, and "speculative" because he is not produced by human action but is instead the object of contemplation. For Aquinas this contemplation of God is the supreme human good, the only true eudaimonia and common good par excellence.

In Aquinas' teaching, therefore, we find a correspondence between the common good in predication and the common good which refers to a "universal whole", between the common good as an extrinsic cause and God as the common good referred to as a "potential whole", and between the common good as an intrinsic cause and eudaimonia as the common good referred to as a "integral whole" in which citizens themselves participate as the formal and actual parts by means of the bona communia as the material and potential parts.

The analogy of the common good developed in Aquinas' teaching allows for the usage of the term in other contexts aside from the polis. The common good could be employed in reference to God or to the order in the universe, for example. God as the common good becomes the highest object of contemplation not only for a privileged few, as in the Aristotelian polis, but for every human being, at least, potentially. The common good could also be used with regard to the family, specifically, to the children as the common good of both spouses (Smith 1995: 76, Walshe 2006: 242). Husband and wife come together for the purpose of begetting children and educating them. Each child is a good of the father only insofar as it is also a good of the mother, and a child's being a good for each parent is inseparable from its being a good for both spouses. Neither parent can beget a child alone; yet that it has been begotten by both does not diminish each parent's participation in the child's generation: the "mine” and the "yours" of each spouse are inextricably fused into the "ours" of both parents. In the family as in the polis, the dynamics of the common good is the same. 
After all of these clarifications, we are now in a position to identify the common good of the firm: the production of goods and services in which human beings participate through work. From the Aristotelian viewpoint, this is the good of the firm as an intermediate association and of each of its members of; collectively, it is also their highest good. In the measure that the firm achieves this goal, it fulfils its purpose or function: it is a "good firm", well-governed and makes its members good. And in the same way that citizens participate in the common good of the polis or state by exercising their citizenship, that is, by engaging in joint political deliberation, decision and action, workers participate in the common good of the firm by carrying out their productive activity in common.

From the Thomistic perspective, this common good of the firm may be described as intrinsic, social and practical. It is "practical” because it refers to productive work, the activity realized by the members of the firm; "social” because it cannot be achieved by any single member but depends on the coordinated effort of a community of persons; and "intrinsic" because it is internal to the firm and cannot exist independently of it. This common good of the firm could also be described as an "integral whole" wherein workers are "formal" and "actual" parts. Workers are "actual” parts because, strictly speaking, they realize the common good of the firm only when they carry out their productive activity on its behalf and not in their other endeavors. And they are "formal" parts because they engage in their work as free, intelligent and unique agents which could never really be replaced or substituted by others. The "material" and "potential" parts of the common good of the firm as an "integral whole" would analogously refer to the sum total of nonpersonal conditions, resources, instruments and means that make work and production possible.

Notice that our definition of the common good of the firm does not relate, at first hand, to the goods and services in themselves, as material, tangible or objective realities. The common good of the firm does not lie primarily in these material things, but in their production, in the the joint effort or work of a group of human beings. That production, joint activity or work in common, then, is the reason people come together and constitute the firm as an intermediate community. Certainly their activity does not take place in a void, as if they were pure spirits. Material resources and conditions are 
needed, but they share more directly in the work that produces the goods and services than in the resulting goods and services as such. For example, maintenance personnel at a university do not deliver lectures, but they participate in the collective effort that allows the university as an institution to teach. In a direct manner, teaching is incumbent only upon professors.

The emphasis on production instead of the goods and services produced is because the common good of the firm is, first and foremost, a network of activities, a host of practices; it is work in common. To be sure, work consists in a purposive and free human act (NE 1111a), although not all purposive and free human acts qualify as work. Rather, work is normally reserved to designate productive actions exclusively (NE 1139a-b). Productive actions are those which focus on concrete, individual objects, with a view to changing or transforming them. They differ from pure theory or abstract thought, which simply aims at uncovering or reflecting what is universal and necessary in reality.

Work is a form of activity, and activities themselves are ideally of two kinds: making (poiesis) or doing (praxis) (Pltcs 1254a). In Aristotle’s time, productive work was identified with poiesis, and as such, it was not the sort of activity in which citizens would engage. Rather, it was reserved for slaves and foreign workers. During Aquinas' time, however, the intellectual activity (study, preaching or lecturing, akin to praxis) carried out by the members of the Mendicant Orders came to be recognized as a form of spiritual work (De opere manuali, a. 2; Contra impugnantes Dei religionem et cultum, c. 5). The radical separation between poiesis and praxis, therefore, started to disappear, and with it came a growing cognizance of the double nature of work. This insight has reached its most advanced stage of development in Church Social Doctrine.

Each time a human beings acts on previously existing matter, two different results can be expected. The first is an objective result, usually something capable of independent existence from the human agent, or at least, something that manifests itself externally and is observable by others. The second is a subjective result that inheres in the agent himself and is inseparable from him; it need not show itself directly to the outside, although it would have consequences in his actions. 
Examples of making (poiesis) would be the crafts (techne) and the fine arts (NE 1174a). What is important in making is the external object itself, considered as a work of art or craft, with the skill of the artist or artisan taking second place. How does one differentiate between the work of an artisan and that of an artist? Whereas the rule or norm for craftsmanship is external to production itself, in the fine arts, it is internal. In the crafts, the procedure or steps to be taken could, in principle, be externally observed and expressed in instructions or guidelines. In theory, by following a craft instructions manual, anyone could obtain guaranteed results. In the fine arts, however, no such set of instructions nor guarantee exists. Instead, the rule is heuristic and idiosyncratic to each work of art. That's why objects belonging to the crafts could be mass-produced, while those belonging to the fine arts are unique.

The other kind of activity that centers on the subjective result is what we normally call doing (praxis). As an activity, it is more immanent or reflexive than transient or transitive; it proceeds from the agent and ends in himself, not in an external object. The human being is, at the same time, agent and patient of the production process. In a remarkable sense, we are before a process of "self-production", where man is maker (homo faber) of himself. The main result of doing is not an artifact, but an operative moral habit or virtue. Through the acquisition of virtues, the process of "selfproduction” becomes, at the same time, a process of self-perfection. While making is guided by the skills either of craftsmanship or of a fine art, doing is guided above all by the habit of prudence, practical reasoning or practical wisdom.

Nowadays, we understand that making and doing are two inseparable dimensions present in any form of work or productive human activity. In theory, one could choose to put a greater emphasis on the external result (making or poiesis) than on the internal result (doing or praxis). As said earlier, for Aristotle, this would be the case with the productive or working class. Not being citizens, they participate very limitedly in the political common good. This alternative, however, would be inconsistent with the principles of Church Social Teaching which, aside from acknowledging the fundamental equality among all human beings, also grants primacy to the internal or subjective dimension of work over its external or objective dimension (Laborem exercens 6; Compendium of the Social Doctrine of the Church, henceforth, CSDC 270- 
271). For Aristotle, this would only be possible for the elite, made up of citizens engaged in leisure, democratic deliberation and contemplation.

We have now come to realize that human beings are always more important than the things they produce. And although in the course of their work, they have a chance to develop the skills of craftsmanship and the fine arts, these are secondary in importance to the moral virtues they could acquire. Work is not a mere commodity for economic exchange or a simple factor of productivity.

The common good of the firm is the work in common that allows human beings not only to produce goods and services (the objective dimension), but more importantly, to develop technical, artistic and moral virtues (the subjective dimension). Among the latter, entrepreneurial initiative, creativity and cooperation deserve special mention (CSDC 336).

Aside from the productive activity per se, working in a firm also serves as an occasion for meaningful exchange, relationship and encounter among human beings. Because of its intrinsic social dimension (CSDC 273), work is, at the same time, the manner in which human beings participate in the firm. Participation through work is simultaneously a duty and a right. It is a duty insofar as every human being is expected to contribute to the development of economic, cultural, political and social life (CSDC 189). And it is a right because work enables human beings to share not only in a firm's profits, but also, to the extent possible, in its management and ownership (CSDC 281).

Participation in the common good of the firm is, therefore, not limited to the shareholders only, as the dominant financial theory of the firm suggests (Friedman 1970), but it is also open to other stakeholders or interest groups (Freeman 1984). Shareholders participate in the measure that the financial resources they contribute represent their accumulated or capitalized work, put at the service of the firm. We could proceed analogously with each and every stakeholder group, tracing their participation through the work they perform: employees, customers, suppliers, competitors and so forth (Sison 2008: 86-93). There is a hierarchy, however, to be observed among them, such that persons take precedence over non-persons such as the environment, and direct stakeholders over indirect stakeholders. Management workers who, at the same time, 
have equity stakes in the firm are the best positioned to contribute, achieve and benefit from the common good of the firm.

Effective participation in the common good of the firm is never automatic. It requires the virtue of justice, both in its distributive and legal forms. Distributive justice refers to the duties and obligations of the whole - in this case, the firm - to its parts, while legal justice spells out the duties and obligations of the parts — primarily, workers and other stakeholders - to the whole. Distributive justice demands, for instance, paying a just wage, while legal justice requires that workers dedicate their best efforts to the firm and that they take care of its resources. In a relationship, duties and obligations of one party always correspond to the rights of another. So to insist on the fulfilment of duties and obligations necessarily entails the respect and observance of rights, both in the personal as well as in the institutional levels. Yet to conceive the whole gamut of personal and institutional relationships taking place in the firm exclusively in terms of rights and responsibilities would be an impoverished view. For justice and law can only prescribe minimum conditions, not the states of excellence or perfection in virtue that should be pursued.

Moreover, for a firm to fulfil its common good, it is necessary that the goods and services produced in common be truly useful, that is, that they satisfy the legitimate needs and wants of people in the market. Production or work in common must also seek to make the best use of the limited resources available; in other words, it should strive to be efficient. Only then would businesses be able to comply with their social function of contributing to the wider common good, by observing economic discipline while at the same time upholding superior values (CSDC 338).

\section{The structure of the common good of the firm and subsidiarity}

In an insightful commentary Millán-Puelles (1971) speaks of the political common good in Church Social Teaching as a hierarchical structure composed of three levels. These levels are, from the lowest to the highest, material well-being, peace and concord, and cultural values widely construed. Material well-being should not be confused with the material goods necessary for it. Rather, it is the satisfaction that one derives participating in such goods. Material goods - earlier referred to as bona 
communia - are external means or instruments that lead to a sense of satisfaction or well-being. Surprisingly, satisfaction or well-being in itself is not material. This is, of course, consistent with the view of the human being as a substantial unity composed of body and soul. Material well-being forms part of the common good because it is necessary that each and every member of society have sufficient means for a decent life. It is not simply a matter of meeting the biological requirements for survival, but of making social life and acts of virtue possible (Rerum novarum 25).

The next level represented by peace and concord does not depend exclusively on material goods, although it demands a minimum of them. At the same time, there could even be an abundance of material goods without achieving material well-being, due to unjust distribution. A just distribution of material resources among the members of society is a requisite for there to be peace and concord. St. Augustine defines peace as the "tranquillity in order" (De civitate 1. 19, c. 13) experienced not by individuals alone but by the entire political community. Aquinas, for his part, describes concord as the condition when two men freely agree to something that is good for both, resulting in true peace (ST II-II, q. 29, a. 3, ad 1). Concord cannot come about by fear, coercion or imposition. This is not to say that there is no room for the use of force or violence in a society that adheres to the common good; only that force and violence are the prerogatives solely of the legitimate ruler in his role as guardian of justice (ST II-II, q. 66 , a.8). In the same way that material well-being is a condition for peace and concord, peace and concord are indispensable for human beings to be able to share and participate in superior cultural values.

Cultural values include a broad variety of technical, artistic, intellectual, ethical and spiritual goods. They may not present themselves with the same urgency as the two previous levels, but they are even more important for authentic human flourishing and perfection as they belong to a superior order. The reason we seek peace and concord is that they facilitate participation in these cultural values catering to the higher aspirations of human beings. And this should be the case for all of members of society, not only for the elite.

Each of these levels is to be integrated into an organic, living whole, such that if any one were lacking, the other two would be unable to fulfil their function properly. 
There is a positive feedback loop among all three. Material well-being for all promotes peace and concord, but so do peace and concord promote material well-being for everyone. Peace and concord facilitate the realization of cultural values, but so do cultural values facilitate peace and concord. And the same relationship holds between material well-being and cultural values. Nonetheless, a hierarchical order still ought to be observed, such that the lower level is put at the service of the higher. Peace and concord certainly requires the just distribution of material means among the populace. However, this should be done not simply to increase their material well-being but, above all, to further their spiritual and moral perfection.

This same the three-level synthesis proposed by Millán-Puelles (1971) regarding the structure of the political common good could be applied to the corporate common good. In the case of the firm, material well-being refers to the factors or conditions that affect its economic viability and sustainability, such as profits. Profits are an indicator of how well the firm is doing, but their generation per se cannot be the purpose of the firm nor exhaust its common good (Centessimus annus 43). Next, peace and concord would correspond to good governance or management practices, in establishing the right rules, procedures and structures. And finally, cultural values in a broad sense would encompass not only technical know-how but also artistic, ethical and spiritual values, including an openness to God that one can develop through the course of his work. Managers should constantly keep an eye on all three levels, instead of mistakenly thinking that enlightened governance practices would only matter once certain profit levels have been attained, or that concerns for the further cultural development of workers must only be taken into account when labor relations are in smooth sailing. Oftentimes, solutions to problems in one level are to be found in the superior one, given the positive feedback loop among all three.

Having explained the content and structure of the corporate common good, we could now establish its relation to the political common good. The common good of the firm is a particular good with regard to the common good of the larger society. The appropriate relationship between the state or polis and an intermediate group such as the firm is one of "subsidiarity" (CSDC 186-7). Given that both the state and firms have their own legitimate objectives and spheres of action, they owe each other mutual respect, notwithstanding the proper hierarchy beween them which acknowledges the 
superiority of the state. There is a double dimension to the state's role with regard to business firms as intermediate associations. It is incumbent upon the state as the superior-order society to positively help, support and assist —even to promote and develop- lesser order intermediate bodies. Put negatively, the state should refrain from replacing or absorbing intermediate bodies such as firms and misappropriating their functions.

By encouraging the growth of firms as private initiatives, the state contributes to a healthy pluralism and diversity in society. The state should delegate to these groups tasks that they would carry out better by themselves, being in closer contact with the needs and desires of the people. Furthermore, by fostering the legitimate initiatives of intermediate groups, the state makes a more rational and efficient use of limited resources, focusing instead on matters that are of its exclusive competence, such as defense, foreign relations or the administration of justice. Subsidiarity guards against statism in its many forms, from excessive centralization or the usurpation of decisionmaking powers, through bureaucratization or the shirking of personal responsibility, to welfarism or paternalism. The principle of subsidiarity provides the most effective protection against a self-serving state, ensuring that the state serve its citizens and the institutions — such as business firms and corporations - they form.

We are confronted, therefore, by two different communities, each with its own common good. Business firms are artificial and imperfect intermediate associations seeking an economic goal, particularly, the non-natural acquisition or provision of material means for human flourishing. They are subordinated to the political community, the natural and perfect society which provides the context wherein human flourishing takes place. The common good of the firm, the production of goods and services in which human beings participate through work, becomes a particular good with respect to the common good of the political community, eudaimonia or human flourishing. However, the subordination of the firm to the state ought to be governed by the principle of subsidiarity.

In summary, business firms contribute to the political common good in two ways. One is through the goods and services (the objective dimension of the work in common) that satisfy human needs and wants, and the other, through the joint 
production effort itself (the subjective dimension), inasmuch as it provides an opportunity for workers to develop technical, artistic, moral and intellectual virtues. In consonance with the Aristotelian-Thomistic tradition, as well as with Church Social Teachings, the second contribution is superior to the first, although the first is a necessary condition to obtain the second.

IV.Conclusion: Corporate governance as praxis and the common good

At this stage, one thing we have learned for sure. Corporate governance should not consist in the maximization of shareholder value nor in balancing conflicting stakeholder interests, but in seeking the common good of the firm. By the expression the "common good of the firm” we ought to understand "work carried out in common", insofar as it provides an opportunity for self-perfection through the acquisition of virtues (the subjective or praxis dimension) simultaneously with the production of goods and services that society needs (the objective or poiesis dimension). A hierarchy must be observed such that the subjective or praxis dimension always takes precedence over the objective or poiesis dimension of work, notwithstanding the inseparability of the two. Although the objective dimension better reflects the nature of the firm as an economic institution dedicated to the provision of goods and services beyond the capacities of the family, it nevertheless has to be subjected to both ethical (concerning virtue) and political (pertaining to happiness or flourishing) considerations, in line with Aristotelian-Thomistic thinking.

Another way of looking at the common good of the firm, in keeping with Church Social Doctrine, is through a triple-level structure suggested by Millán-Puelles (1971): the material wellbeing of constituents at the base, followed by good management practices that foster justice and harmony, topped by the nurturing of values and virtues. An important proviso for correctly understanding this structure, however, is that one should not wait until the requirements of each level are fully satisfied before attending to those of the next. Requirements are socially, historically and culturally conditioned, and because of this, never absolutely satisfied. Furthermore, it is by focusing on the demands of the superior level, oftentimes, that one is able to adequately address the needs of the inferior one. The higher level is not only the next destination, but it also acts as a guide for the previous one. 
Similarly, the corporate common good should always be viewed with respect to the political common good. Despite its influence and relevance, the firm is but an artificial and imperfect body, and in that regard, inferior to both families and civil society or the state. Although modern society is largely dependent on firms to supply material or economic needs, firms in themselves cannot provide what human beings ultimately desire, that is, a full, flourishing life. Only wider civil society or the state could furnish that. This does not mean, of course, that the state should supplant firms; rather, it should help and encourage them, in accordance with the principle of subsidiarity.

In an important measure, my proposal on the common good of the firm transcends the original Aristotelian understanding of work as poiesis, that is, a purely productive activity not carried out by citizens that results in an external object. To some degree, it also goes beyond the Thomistic conception of work, specifically manual work, the value of which lies in helping us avoid the vice of idleness, in controlling lower bodily instincts and in obtaining sustenance (De opere manuali, a. 1). Although Aquinas, in his discussion, began to make room for the intellectual work, its value remained very much within the realm of the instrumental. In fact, the emphasis on the subjective or praxis dimension of work does not come in full force until several centuries later, with the publication of John Paul II's encyclical in 1981 (Laborem exercens, 6-8). But none of this would have been possible without the conceptual ground-breaking accomplished by Aristotle and Aquinas’ contributions.

If the common good of the firm consists in pursuing work in its two distinguishable but inseparable dimensions, while respecting the priority of the subjective aspect over the objective aspect, then corporate governance itself must be considered as an activity following the praxis model rather than the poiesis or technical model.

Corporate governance actually refers to a distinct and special form of politics, writ small, limited to an intermediate association (Sison 2006). It is an instance of action, rather than of mere production. As such, corporate governance should be analyzed and evaluated on the basis of the changes it introduces in the agent himself, rather than in the agent's surroundings or physical environment. This means that in order to govern well, one needs above all to cultivate the excellences, character traits or virtues (aretai) 
proper to a ruler. These are far more important than the rules, principles or laws that he may later on set down. Not that a good governor could totally dispense with rules, but they are only secondary, to be considered once excellent character traits or virtues are in place. Granted that “rules are meant to be broken”, only the ruler's virtue can ensure that the goods rules are supposed to protect are actually kept safe, even when the rules themselves are overrun. Furthermore, rules by themselves are useless or could even be harmful, unless they are properly interpreted and implemented. And the proper interpretation and implementation of rules depend on the moral and intellectual dispositions —ultimately, the virtues - of the governors or the people entrusted with this function.

Most other approaches consider governance as an activity belonging to the category of poiesis or production. In consequence, they are more concerned with the formulation of some sort of rule-book, as the corresponding external product or object on which the success of the activity rests or should be judged. Their aim seems to be the creation of a fool-proof instructions manual on the task of good governance. There is an undue emphasis on the setting up of structures and the design of processes as if these carried the key. They tend to forget that the outcome of good governance cannot be separated from the internal or personal dispositions — in other words, virtues — of the agent, so much so that it is impossible to perfectly codify a set of rules and institute certain structures and processes, then pretend that their observance alone would guarantee the desired results.

To perform a praxis such as governance well, beyond following the rules, the right intention and moral dispositions aside from the appropriate circumstances also have to be assured. For this there is nothing better than the holistic education of the ruler in the virtues of mind and character. It is not that Aristotle holds written laws or principles in disdain. They certainly form a necessary bulwark against arbitrariness in the governor and exert a powerful influence in molding habit and custom amongst a people. Yet he still thinks that habit and custom are superior to the law, however, for except in the case of physical coercion, it is only from habit and custom that the law could draw force and strength. Whereas the excellence of poiesis is called technique or art, the right reason in production, such as the one used in the crafting of governance laws, structures and 
procedures, that of praxis is called prudence, the right reason in action, the paramount virtue of the ruler or governor.

Indeed, prudence or practical wisdom is a character trait acquired through habit, appropriate mentoring and discipleship, as well as a broad experience. Notwithstanding the doctrine regarding the "unity of the virtues", according to which any particular excellence in character requires all the others for its full development, prudence is said to encompass all the human virtues. Prudence therefore includes moderation or temperance, truthfulness, courage, and so forth, character traits indispensable for a good governor. It is demonstrated in the ability of individuals to judge particular situations on their merits and to act accordingly; not to be confused with the mechanical application of impersonal, purportedly general rules (NE, 1141b). Such rules or laws would be valid perhaps in the realm of the physical and mathematical sciences, but not in human behavior, which being free is messy and unpredictable. If the good in human action is nevertheless to be sought, it should be done with an eye or certain sensitivity to the particular good of the people involved and to the contingency of circumstances (NE 1143b). None of these could be adequately covered by universal laws.

As Kane and Patapan (2006) have pointed out in their reflections on managerial reform, the development of prudence has been thwarted in most institutions and organizations "first, by the imposition of artificial external disciplines on decision making, such as those provided by a market [...]; second, by a general technocratic approach to decision making [...]; and third, by attempts to approach the problem in a counterproductive, piecemeal fashion [...]" (Kane and Patapan 2006: 712). Furthermore, they diagnose an even deeper cause for the current flaws in governance that digs its roots in Weber's analysis of bureaucracy: the substitution of prudence by the rational-legal structures of a purely instrumental form of rationality (ibid.). These are defects glaringly present in the majority of corporate governance codes and literature on best practices. Emphasized are techniques, theories $d u$ jour on human behavior and decision making and short term, tunnel vision objectives while the virtues are completely ignored.

Good governance should be understood primarily as the proper exercise of power and authority at the topmost level of an organization such as the business firm. It refers 
not so much to the "how?", to the ways and means, the rules, structures and procedures to be implemented when exercising power and authority, as to the "what for?", to the purpose or end of whoever exercises them. Such a question warrants a response based on a "good", particularly on the specific contribution to the "common good" of society as a whole that any corporation is meant to deliver. Here we find the ultimate justification for the existence of corporations.

The goods and services produced by the community of persons working in a firm figure in a whole, complex range of material and spiritual goods, internal and external goods, goods in themselves and instrumental goods, the one final good or end and the common good. In order to recognize or "perform” such goods and to assign them their proper place in the hierarchy in cases of conflict, virtue — preeminently, prudence - is needed. A merely physical or mechanical recognition and production or performance of these goods is not enough, if they are to be articulated and seamlessly woven into the larger fabric of societal common good. That's why certain people, at one point or another, sometimes fail to acknowledge and therefore heed the "calling" of a good yearning to be realized. More than anything else, it may be due to their lack of virtue. Excellence of character not only enables one to do things properly, technically and ethically speaking. It also allows him to detect the convenience or need for that good, when many other people of inferior virtue would nonchalantly pass it by, oblivious even of that good's existence. Virtue makes one perspicacious of goods to be achieved in any given circumstance.

Because virtue is needed not only to properly interpret and implement the rules of governance, but also to correctly identify and produce the goods involved, it becomes clear that key to good governance ultimately lies in the education of the governors or rulers. Even the kind of regime dominant in an organization just amounts to a host of formal conditions that best allow for the proper on-going education in the virtues of the governors or rulers. Unless this principle is sufficiently acknowledged, all attempts at corporate governance reform will be, at best, superficial or cosmetic, and at worst, ruefully ineffective, as the already long list of reforms that have preceded it.

The possession of the virtues of mind and character, notably, of prudence, is crucial not only for the proper interpretation and implementation of rules, but also for the 
correct identification and production or performance of the goods that a corporation and its governors should seek, both personally and as a body. Hence, a true and effective corporate governance reform should start with the proper ethical and political education of a firm's directors or governors. Only when this condition is satisfied could any discussion regarding rules, structures, procedures, best practices and so forth meaningfully proceed.

References

Aristotle: Aristotle’s Metaphysics, trans. and notes by C. Kirwan, Oxford (Clarendon Press) 1971.

Aristotle: Nicomachean Ethics, trans. by T. Irwin, Indianapolis, IN (Hackett Publishing) 1985.

Aristotle: The Politics, ed. by S. Everson, Cambridge (Cambridge University Press) 1990.

Aquinas, T.: “De veritate”, Quaestiones disputatae (vol. I), ed. by R. M. Spiazzi, Taurini (Marietti) 1953.

Aquinas, T.: “De perfectione vitae spiritualis”, Opuscula theologica (vol. II), ed. by R. M. Spiazzi, Taurini (Marietti) 1954.

Aquinas, T.: “Commentary on the Nicomachean Ethics”, trans. by E. L. Fortin and P. D. O’Neill, in: Ralph Lerner and Mushin Mahdi (Eds): Medieval Political Philosophy, Ithaca, NY (Cornell University Press) 1962.

Aquinas, T.: “Contra impugnantes Dei religionem et cultum”, Opuscula polemica pro mendicantibus (vol 41 A), Romae (Ad Sanctae Sabinae) (Commissio Leonina), 1970.

Aquinas, T.: “De opere manuali”, Quaestiones de quolibet. Quodlibet VII (vol. 25/2), Roma-Paris (Commissio Leonina-Éditions du Cerf) 1996.

Aquinas, T.: Summa Theologiae, ed. by English Province of the Order of Preachers, Cambridge/New York (Cambridge University Press) 2006.

Augustine of Hippo: The City of God, trans. by G. G. Walsh and D. J. Honan, Washington (Catholic University of America Press.) 1964.

Coase, R.: “The Nature of the Firm”, Economica, 4(16), (1937), pp. 386-405.

Fontrodona, J., Sison, A.J.G.: "The Nature of the Firm, Agency Theory and Shareholder Theory: A Critique from Philosophical Anthropology”, Journal of Business Ethics, 66 (1/II), June (2006), pp. 33-42. 
Freeman, R. E.: Strategic Management: A Stakeholder Approach, Boston (Pitman) 1984.

Friedman, M.: “The Social Responsibility of Business is to Increase its Profits”, The New York Times Magazine, 13 September 1970.

Froelich, G.: “The Equivocal Status of Bonum Commune”, The New Scholasticism, LXIII (Winter), (1989), pp. 38-57.

Jensen, M., Meckling, W.: "The theory of the firm: managerial behavior, agency costs and ownership structure”, Journal of Financial Economics, 3(4), (1976), pp. 305-360.

John Paul II: Encyclical Letter Laborem exercens, 1981.

John Paul II: Encyclical Letter Centessimus annus, 1991.

Kane, J., Patapan, H.: 'In Seach of Prudence: The Hidden Problem of Managerial Reform’, Public Administration Review, September/October (2006), 711-724.

Leo XIII: Encyclical Letter Rerum novarum, 1891.

Millán-Puelles, A.: "Bien común”, Gran Enciclopedia Rialp, vol. 4, Madrid (Ediciones Rialp), (1971), pp. 225-230.

Pontifical Council for Justice and Peace: Compendium of the Social Doctrine of the Church, Rome (Libreria Editrice Vaticana) 2004.

Roberts, J.: The Modern Firm, Oxford/New York (Oxford University Press) 2004.

Samuelson, P. A.: “The Pure Theory of Public Expenditure”, Review of Economics and Statistics, 36 (4), (1954), pp. 387-389.

Sison, A.J.G.: "Governance and government from an Aristotelian perspective”, in: GJ (Deon) Roussouw and Alejo José G. Sison (eds): Global perspectives on ethics of corporate governance, New York (Palgrave MacMillan) 2006, pp. 77-89.

Sison, A.J.G.: "Toward a Common Good Theory of the Firm: The Tasubinsa Case”, Journal of Business Ethics, 74 (4), September (II) (2007), pp. 471-480.

Sison, A.J.G.: Corporate Governance and Ethics. An Aristotelian Approach, Cheltenham, UK/Northampton, MA, USA (Edward Elgar) 2008.

Smith, M.A.: Human Dignity and the Common Good in the Aristotelian Thomistic Tradition, Lewiston/Queenston/Lampeter (Mellen University Press) 1995.

Walshe, S.: The Primacy of the Common Good as the Root of Personal Dignity in the Doctrine of Saint Thomas Aquinas, Rome (Pontifical University of St. Thomas) 2006. 